\title{
PENGEMBANGAN MULTIMEDIA INTERAKTIF BERBASIS MACROMEDIA FLASH PADA PEMBELAJARAN TEMATIK TERPADUKELAS IV SEKOLAH DASAR
}

\author{
Fadhilla Imanda Azzahra, Yanti Fitria \\ Surel: fadhillaimanda1@gmail.com
}

\begin{abstract}
This type of research is $R \& D$ Research (Research and Development). This study uses a 4-D development model, which consists of the stages of definition (define), design (design), development (develop), dissemination (disseminate). The instrument used is expert validation, teacher and student responses. The results of the developed media research show: (1) Interactive multimedia based on macromedia flash on theme 8 sub-theme 2 in elementary school is declared very valid with an average score of $90.6 \%$ media experts, experts material $92 \%$ and linguists $88 \%$, (2) The responses of teachers and students to the interactive multimedia trial based on macromedia flash 8 on theme 8 sub-theme 2 in elementary school obtained a very practical category with an average value of $92.5 \%$ and $88 \%$ (3) The response of teachers and students to the distribution of interactive multimedia based on macromedia flash 8 on theme 8 subtheme 2 in elementary school obtained a very practical category with average values of $95 \%$ and $82.6 \%$
\end{abstract}

Keywords: Development, Macromedia Flash, 4-D Model

\begin{abstract}
ABSTRAK
Jenis penelitian ini adalah Penelitian R\&D (Research and Development). Penelitian ini menggunakan model pengembangan 4-D, yang terdiri dari tahapan definisi (define), desain (design), pengembangan (develop), diseminasi (disseminate). Instrumen yang digunakan adalah validasi ahli, respon guru dan siswa. Hasil penelitian media yang dikembangkan menunjukkan: (1) Multimedia interaktif berbasis macromedia flash pada tema 8 subtema 2 di SD dinyatakan sangat valid dengan skor rata-rata ahli media 90,6\%, ahli materi $92 \%$ dan ahli bahasa $88 \%$, (2) Tanggapan guru dan siswa terhadap uji coba multimedia interaktif berbasis macromedia flash 8 tema 8 subtema 2 di SD memperoleh kategori sangat praktis dengan nilai rata-rata $92,5 \%$ dan $88 \%$ (3) Tanggapan jumlah guru dan siswa terhadap pendistribusian multimedia interaktif berbasis macromedia flash 8 pada tema 8 subtema 2 di SD memperoleh kategori sangat praktis dengan nilai rata-rata $95 \%$ dan $82,6 \%$
\end{abstract}

Kata Kunci: Pengembangan, Macromedia Flash, Model 4-D

\section{PENDAHULUAN}

Meningkatkan

pendidikan

adalah salah satu usaha dalam meningkatkan kualitas pendidikan (Yetri, Fauzan, Desyandri, Fitria dan Fahrudin, 2019). Kebutuhan yang sangat penting bagi manusia salah satunya adalah pendidikan. Baik dari bidang akademik maupun dari bidang non-akademik. Karena dalam meningkatkan kualitas sumber daya dimasa yang akan datang sangat 
Fadhilla Imanda Azzahra, Yanti Fitria: Pengembangan Multimedia ....

diperlukannya pendidikan. Hal ini senada dengan pernyataan Elisa, Leni, Hadiyanto, Fitria (2019) yang menyatakan bahwa pendidikan merupakan "a planned activity or process carried out by related components to develop self potential, maximize ability, increase knowledge, improve spiritual spirit and have personality that is expected to be suitable with educational goals it self". Pendidikan merupakan suatu proses dalam pembentukan kepribadian yang sesuai dengan tujuan pendidikan itu sendiri. Seiring dengan perkembangan zaman, dunia pendidikan pun telah mengalami perubahan-perubahan, salah satunya yaitu dengan diperbaharuinya kurikulum (Retnaningsih, 2012).

Menurut Anastasha, Fitria \& Idamurni (dalam Indriyani, Desyandri, Fitria, dan Idamurni, 2019) tujuan pembelajaran tematik terpadu adalah menjadikan siswa menjadi pribadi yang lebih kritis, aktif dan terlibat langsung dalam proses pembelajaran. Sejalan dengan pendapat Amini dan Helsa (dalam Indriyani, Desyandri, Fitria, dan Idamurni, 2019) mengatakan bahwa pembelajaran tematik bertujuan agar dalam proses pembelajaran siswa dapat terlibat langsung dan dapat menjadikan siswa lebih aktif dan memperoleh pengalaman secara langsung. Hal ini senada dengan tujuan kurikulum 2013 yaitu untuk menciptakan pembelajaran yang bermakna. Kurikulum 2013 adalah kurikulum yang mengutamakan keterampilan, pemahaman dan pendidikan karakter (Andini dan Fitria, 2021). Menurut Yanti Fitria (2016) merupakan faktor utama penentu keberhasilan program pendidikan khususnya pada level pendidikan dasar adalah guru. Yanti Fitria (2018) mengatakan bahwa pembelajaran harus mempunyai makna dan berpusat pada kebutuhan dan perkembangan siswa. Dengan semakin berkembangnya ilmu pengetahuan dan teknologi (IPTEK) maka zaman pun semakin berkembang pula. Perkembangan IPTEK sendiri memberikan pengaruh yang sangat besar terhadap berbagai bidang kehidupan termasuk dalam bidang pendidikan. Upaya-upayapada pembaharuan dan pemanfaatan hasil teknologi dalam proses belajar mengajar, serta dalam mempermudah dan mengefesienkan proses belajar mengajar melalui pengaplikasian media pembelajaran merupakan Salah satu pengaruh IPTEK dalam duniapendidikan.

Menurut Daryanti, Desyandri dan Fitria (2019) salah satu penunjang pendidikan yang sangat penting adalah media pembelajaran yang baik. Tanpa media, interaksi yang dilakukan antara guru dengan siswa tidak akan berlangsung dengan optimal. Menurut Taupik dan Fitria (2021) mengatakan bahwa pembelajaran inovatif merupakan pembelajaran yang terpusat pada siswa atau siswa secara aktif terlibat dalam proses pembelajaran. Media pembelajaran adalah wahana dan penyampaianpesanatau informasiyang terdapat dalam pembelajaran kepada 
siswa (Marpaung dan Siagian, 2016).

Menurut

Hamalik

(1984)media pembelajaran adalah sebuah alat, teknik dan metode yang berguna untuk mengefektifkan komunikasi dan interaksi dalam proses pembelajaran dan pengajaran di sekolah.Menurut Rusman, dkk (2011) media pembelajaran adalah sesuatu alat yang digunakan untuk menyampaikan pesan serta dapat menstimulus pikiran, perhatian, perasaan dan kemauan belajar siswa sehingga dapat mendorong terjadinya proses belajar mengajar yang bertujuan dan terkendali. Merujuk dari kegunaan media, sekiranya membuat semua orang akan memikirkan hal yang sama bahwa media sangat mempengaruhi proses belajar mengajar. Dalam proses pembelajaran, penggunaan teknologi memiliki dampak yang baik terhadap kualitas pembelajaran (Wayugi dan Fatmariza, 2021). Dengan bervariasinya gambar dan warna pada media pembelajaran, membuat siswa menjadi tertarik dengan materi yang diberikan oleh guru. Hal ini didukung oleh pernyataan Daryanto (2016) yang mengatakan bahwa persentase kemampuan daya serap manusia yaitu penglihatan $82 \%$, pendengaran $11 \%$, penciuman $1 \%$, pengecapan $2,5 \%$, dan perabaan $3,5 \%$. Ini artinya proses belajar mengajar yang menggunakan media akan lebih mempengaruhi untuk menunjang daya serap siswa.

$$
\text { Dengan berkembangnya }
$$

zaman, guru-guru bisa menemukan software-software yang dapat menunjang proses pembelajaran, diantaranya Power Point, Macromedia Flash 8, Lectora Inspire, Adobe Falsh dan lain - lain. Salah satu software yang dapat menunjang pembelajaran saat ini yaitu Macromedia Flash 8. Ariani dan Dany dalam Mar'atush muntaha rahmi dkk (2019 : 180) menjelaskan bahwa "Multimedia adalah hasil perpaduan antara berbagai media yang berupa teks, gambar, grafik, sound, animasi dan video yang digunakan untuk menyampaikan pesan kepada publik". Salah satu multimedia yang dapat membuat animasi, gambar dan video dengan cara yang mudah dan efektif adalah Macromedia Flash 8. Menurut Fakhri (2018) Dengan Macromedia Flash 8 hal yang berbentuk abstrak bisa dijadikan konkrit melalui berbagai bentuk animasi yang disajikan, sehingga dapat menarik minta siswa saat ditampikan ke hadapan siswa. Menurut Hakim dalam Rena Lestari (2014) Macromedia Flash adalah sebuah program yang dirancang untuk membuat animasi dan aplikasi web profesional. Tidak hanya itu, para pembuat game, animasi kartun dan aplikasi multimedia interaktif seperti demo produk, dan tutorial interaktif juga banyak yang memilih Macromedia Flash sebagai pilihan softwarenya.

Hasil observasi yang sudah peneliti laksanakan pada SDN 32 Bungo Pasang diperoleh informasi bahwa dalam proses pembelajaran masih minimnya penggunaan media pembelajaran, guru kelas hanya menggunakan media konvensional 
Fadhilla Imanda Azzahra, Yanti Fitria: Pengembangan Multimedia ....

dalam mengajar, seperti media gambar ataupun media visual seperti video dari Youtube dan power pointsederhana. Hal ini dikarenakan kurangnya kompetensi guru dalam mengoperasikan media pembelajaran yang berbasis software dan juga faktor usia yang kurang membantu dalam pemahaman pelatihan teknologi informasi dan komunikasi yang pernah disampaikan.

\section{METODE PENELITIAN}

Penelitian yang dilakukan adalah penelitian Research an Development. Sugiyono (2018) mengatakan bahwa penelitian dan pengembanganmerupakan suatu penelitian untuk mengembangkan produk baru atau menyempurnakan produk yang telah ada serta menguji keefektivitasan produk tersebut.

Sebelum dilakukan ujicoba, media terlebih dahulu divalidasi oleh para ahli setelah media dinyatakan valid maka media sudah boleh di ujicobakan. Uji coba produk nantinya akan dilakukan oleh guru dan peserta didik kelas IV SDN 32 Bungo Pasang. Penelitian ujicoba tersebut akan dilakukan sesuai jumlah siswa yang ada di kelas tersebut. Uji coba praktikalitas bertujuan untuk mendapatkan informasi apakah media pembelajaran yang dibuat praktis digunakan di kelas IV dalam pelaksanaan pembelajaran. Praktikalitas ini juga berguna untuk melihat keterpakaian media pembelajaran yang telah direvisi berdasarkan penilaian validator oleh guru dan peserta didik dalam melaksanakan proses pembelajaran. Praktikalitas diperoleh dari hasil respon guru dan peserta didik.

Subjek uji coba dalam penelitian ini adalah 1 orang guru kelas IV dan 12 orang siswa kelas IV SDN 32 Bungo Pasang, sedangkan subjek penyebaran dalam penelitian ini adalah 1 orang guru kelas IV dan 15 orang siswa kelas IV SDN 24 Jati Gaung. Instrumen yang digunakan adalah lembar validasi ahli, angket respon guru dan siswa.

\section{HASIL PENELITIAN DAN PEMBAHASAN}

Data validasi media diperoleh dari satu orang ahli media yaitu bapak Atri Waldi, S. Pd, M. Pd selaku dosen PGSD FIP UNP. Validasi dilakukan dengan cara memberi penilaian angket bentuk desain yang disajikan dalam media. Angket validasi media terdapat 15 pertanyaan. Pengambilan data validasi ahli media dilakukan pertama kali pada hari Kamistanggal 6 Mei 2021 kemudian validasi kedua pada hari Senin tanggal 10Mei 2021. Rincian Analisis data aspek media sebelum dan sesudah revisi dapat dilihat pada tabel berikut: 
SCHOOL EDUCATION JOURNAL VOLUME 11 NO. 3 DESEMBER 2021

Tabel 1. Hasil Validasi Ahli Media

\begin{tabular}{|c|c|c|c|}
\hline & \multirow{2}{*}{ Butir Penilaian } & \multicolumn{2}{|c|}{ Penilaian } \\
\hline & & Penilaian I & Penilaian II \\
\hline 1 & Kejelasan petunjuk penggunaan multimedia & 3 & 5 \\
\hline 2 & Keinteraktifan multimedia & 5 & 5 \\
\hline 3 & Kemudahan pengoperasian symbol & 5 & 5 \\
\hline 4 & Ketepatan penggunaan symbol & 5 & 5 \\
\hline 5 & Kelancaran multimedia ketika dijalankan & 4 & 4 \\
\hline 6 & Kemenarikan tampilan soal dan jawaban soal evaluasi & 4 & 4 \\
\hline 7 & Keterbacaan materi yang disajikan & 4 & 4 \\
\hline 8 & $\begin{array}{l}\text { Kesesuaian tata letak dan visual benda di setiap setting } \\
\text { tempat }\end{array}$ & 3 & 4 \\
\hline 9 & Kesesuaian tampilan warna background & 1 & 4 \\
\hline 10 & Keterbacaan teks & 5 & 5 \\
\hline 11 & $\begin{array}{l}\text { Kesesuaian jenis dan ukuran huruf dengan tampilan } \\
\text { multimedia }\end{array}$ & 4 & 4 \\
\hline 12 & Kesesuaian gambar dengan materi pelajaran & 5 & 5 \\
\hline 13 & Kesesuaian video dengan materi pelajaran & 5 & 5 \\
\hline 14 & $\begin{array}{l}\text { Kesesuaian efek suara dengan kondisi yang sedang } \\
\text { berlangsung }\end{array}$ & 4 & 4 \\
\hline 15 & $\begin{array}{l}\text { Multimedia interaktif dapat memotivasi siswa untuk } \\
\text { belajar }\end{array}$ & 5 & 5 \\
\hline & Jumlah Skor yang Diperoleh & 62 & 68 \\
\hline & Jumlah Skor Maksimum & 75 & 75 \\
\hline
\end{tabular}

Dari data tabel di atas dapat dilihat bahwa jumlah nilai dari validator media setelah direvisi adalah 90,6\%secara keseluruhan aspek media berada pada kategori "sangat baik" menurut kategori penilaian oleh Riduwan dan Sunarto (2012) sehingga dapat dikatakan valid dan dapat dilakukan uji coba.

Data validasi materi diperoleh dari satu orang ahli materi yaitu Ibu Yarisda Ningsih, S. Pd, M. Pd selaku dosen PGSD FIP UNP. Rincian Analisis data aspek materi sebelum dan sesudah revisi dapat dilihat pada tabel berikut:

Tabel 2. Hasil Validasi Ahli Materi

\begin{tabular}{c|l|c|c}
\hline \multirow{2}{*}{} & \multicolumn{1}{|c|}{ Butir Penilaian } & \multicolumn{2}{c}{ Penilaian } \\
\cline { 2 - 4 } & \multicolumn{1}{|c}{ Penilaian I } & Penilaian II \\
\hline 1 & $\begin{array}{l}\text { Kesesuaian pokok bahasan multimedia interaktif dengan materi kelas IV } \\
\text { Tema 8 Subtema 2 Pembelajaran 1 dan 2 }\end{array}$ & 5 \\
\hline 2 & $\begin{array}{l}\text { Penyampaian materi menggunakan bahasa yang komunikatif dan } \\
\text { sederhana }\end{array}$ & 5 & 5 \\
\hline 3 & \begin{tabular}{l} 
Tersedianya soal evaluasi untuk menguji kemampuan siswa \\
\hline
\end{tabular}
\end{tabular}


Fadhilla Imanda Azzahra, Yanti Fitria: Pengembangan Multimedia ....

\begin{tabular}{c|l|c|c}
\hline 4 & Penyajian uraian materi secara utuh & 2 & 5 \\
\hline 5 & Ketuntasan materi kelasIV team 8 subtema 2 pembelajaran 1 dan 2 & 3 & 5 \\
\hline 6 & Pemberian evaluasi untuk pemahaman materi & 4 & 4 \\
\hline 7 & Kejelasan materi pada multimedia interaktif & 3 & 4 \\
\hline 8 & Kejelasan evaluasi pada multimedia interaktif & 4 & 4 \\
\hline 9 & Penyampaian materi memenuhi kebutuhan siswa kelas IV SD & 5 & 5 \\
\hline 10 & $\begin{array}{l}\text { Kemudahan pemahaman konsep materi kelas IV tema 8 subtema 2 } \\
\text { pembelajaran 1 dan 2 untuk memenuhi kebutuhan siswa }\end{array}$ & 5 & 5 \\
\hline 11 & Penyajian materi secara runtut & 5 & 5 \\
\hline 12 & Penulisan materi secara sistematis & 5 & 5 \\
\hline 13 & Keterkaitan soal dengan materi & $\mathbf{7 5}$ & $\mathbf{7 5}$ \\
\hline 14 & Tersedianya gambar dan video yang sesuai dengan materi & 5 & 5 \\
\hline 15 & $\begin{array}{l}\text { Kebenaran dan keterkinian materi kelas IV tema 8 subtema } \\
\text { pembelajaran 1 dan 2 }\end{array}$ & $\mathbf{5 9}$ & $\mathbf{6 9}$ \\
\hline & Jumlah Skor yang Diperoleh & & 5 \\
\hline
\end{tabular}

Dari data tabel di atas dapat dilihat bahwa jumlah nilai dari validator materi setelah direvisi adalah $92 \%$ secara keseluruhan untuk aspek materi sudah berada pada kategori "sangat baik" menurut kategori penilaian Riduwan dan Sunarto (2012) sehingga dapat dikatakan valid dan dapat dilakukan uji coba.
Data validasi bahasa diperoleh dari satu orang ahli bahasa yaitu Ibu Ari Suriani, S. Pd, M. Pd selaku dosen PGSD FIP UNP. Angket validasi bahasa untuk ahli bahasa terdapat 5 pertanyaan. Rincian Analisis data aspek bahasa sebelum dan sesudah revisi dapat dilihat pada tabel berikut:

Tabel 3. Hasil Validasi Ahli Bahasa

\begin{tabular}{c|l|c|c}
\hline \multirow{2}{*}{} & \multicolumn{1}{|c|}{ Butir Penilaian } & \multicolumn{2}{c}{ Penilaian } \\
\cline { 3 - 4 } & \multicolumn{1}{|c}{ Penilaian I } & Penilaian II \\
\hline 1 & Petunjuk penggunaan multimedia disampaikan dengan jelas & 2 & 4 \\
\hline 2 & $\begin{array}{l}\text { Istilah yang digunakan tepat dan sesuai dengan karakteristik siswa } \\
\text { kelas IV SD }\end{array}$ & 3 & 5 \\
\hline 3 & $\begin{array}{l}\text { Penggunaan bahasa mendukung kemudahan memahami alur } \\
\text { materi }\end{array}$ & 3 & 4 \\
\hline 4 & \begin{tabular}{l} 
Penggunaan bahasa yang santun. \\
\hline 5
\end{tabular} & 3 & 5 \\
\hline
\end{tabular}


SCHOOL EDUCATION JOURNAL VOLUME 11 NO. 3 DESEMBER 2021

\begin{tabular}{c|c|c}
\hline Jumlah Skor yang Diperoleh & 14 & 22 \\
\hline Jumlah Skor Maksimum & 25 & 25 \\
\hline
\end{tabular}

Dari data tabel di atas dapat dilihat bahwa jumlah nilai dari validator bahasa setelah direvisi adalah $88 \%$ secara keseluruhan untuk aspek bahasa sudah berada pada kategori "sangat baik" menurut kategori penilaian Riduwan dan Sunarto (2012) sehingga dapat dikatakan valid dan dapat dilakukan uji coba. Uji coba dilakukan dalam skala terbatas di SDN 32 Bungo Pasangpada siswa kelas IV Shift 1 tanggal 19 Mei 2021. Dari nilai akhir praktikalitas respon siswa yaitu $88 \%$ diatas dapat dikatakan "sangat praktis" pada kategori penilaian Riduwan dan Sunarto (2012:23) yaitu kategori pertama dengan presentase
81-100\% untuk itu hasil praktikalitas media pembelajaran berbasis macromedia flash 8 dinyatakan praktis digunakan.

\section{Pembahasan}

Uji coba untuk guru dilakukan pada wali kelas IV SDN 32 Bungo Pasang yaitu bapak Arespi Junindra, S. Pd waktu pelaksanaan tanggal 24 Mei 2021 bertepatan diruang kelas IV SDN 32 Bungo Pasang. Hasil pengisian angket respon guru adalah sebagai berikut :

Tabel 4. Hasil Respon Siswa Terhadap Ujicoba Media

\begin{tabular}{|c|c|c|}
\hline & Indikator & Penilaian \\
\hline 1 & Kemenarikan tampilan Macromedia Flash 8 untuk dipelajari oleh siswa & 4 \\
\hline 2 & Kejelasan tulisan pada Macromedia Flash 8 & 4 \\
\hline 3 & $\begin{array}{l}\text { Tata bahasa dan penyusunan kalimat pada Macromedia Flash } 8 \text { untuk dimengerti oleh } \\
\text { siswa }\end{array}$ & 3 \\
\hline 4 & $\begin{array}{l}\text { Kesesuaian materi pada Macromedia Flash } 8 \text { dengan materi pokok dalam Kompetensi } \\
\text { dasar }\end{array}$ & 3 \\
\hline 5 & $\begin{array}{l}\text { Kesesuaian materi pada macromedia flash } 8 \text { dengan tujuan pembelajaran yang akan } \\
\text { dicapai }\end{array}$ & 4 \\
\hline 6 & Penyajian gambar pada macromedia flash 8 menarik dan proporsional & 4 \\
\hline 7 & Kemampuan media dalam meningkatkan motivasi belajar siswa & 4 \\
\hline 8 & Fleksibilitas penggunaan media dalam pembelajaran & 3 \\
\hline 9 & Kemudahan media untuk memahami materi yang akan disajikan & 4 \\
\hline 10 & Kemampuan media untuk menambah pengetahuan siswa & 4 \\
\hline \multicolumn{2}{|r|}{ Jumlah Skor yang Diberikan Responden (R) } & 37 \\
\hline & Jumlah Skor Maksimum (SM) & 40 \\
\hline
\end{tabular}


Fadhilla Imanda Azzahra, Yanti Fitria: Pengembangan Multimedia ....

Dari nilai akhir praktikalitas respon guru yaitu $92,5 \%$ diatas dapat dikatakan "sangat praktis" pada kategori penilaian Riduwan dan Sunarto (2012:23) yaitu kategori pertama dengan presentase $81-100 \%$ untuk itu hasil praktikalitas media pembelajaran berbasis macromedia flash dinyatakan praktis digunakan.

Penyebaran dilakukan dalam skala luas di SDN 24 Jati Gaung pada siswa kelas IV Shift 1 tanggal 12 Juni 2021. Penyebaran ini dilakukan setelah peneliti melakukan uji coba produk di SDN 32 Bungo Pasang. Penyebaran bertujuan untuk menguji kepraktisan media dalam skala yang lebih luas. Penyebaran ini dilakukan 1 shift pembelajaran dengan siswa sebanyak 15 orang.

Dari nilai akhir praktikalitas respon siswa yaitu $82,6 \%$ diatas dapat dikatakan "sangat praktis" pada kategori penilaian Riduwan dan Sunarto (2012:23) yaitu kategori pertama dengan presentase $81-100 \%$ untuk itu hasil praktikalitas media pembelajaran berbasis macromedia flash 8 dinyatakan praktis digunakan. Penyebaran untuk guru dilakukan pada wali kelas IV SDN 24 Jati Gaung yaitu Ibu Indra Sari, S. Pd waktu pelaksanaan tanggal 12 Juni 2021 bertepatan diruang kelas IV SDN 24 Jati Gaung. Perhitungan hasil praktikalitas dari angket respon siswa adalah sebagai berikut:

Tabel 5. Hasil Respon Siswa Terhadap Penyebaran Media

\begin{tabular}{|c|c|c|}
\hline & Indikator & Penilaian \\
\hline 1 & Kemenarikan tampilan Macromedia Flash 8 untuk dipelajari oleh siswa & 4 \\
\hline 2 & Kejelasan tulisan pada Macromedia Flash 8 & 4 \\
\hline 3 & $\begin{array}{l}\text { Tata bahasa dan penyusunan kalimat oada Macromedia Flash } 8 \text { untuk dimengerti } \\
\text { oleh siswa }\end{array}$ & 3 \\
\hline 4 & $\begin{array}{l}\text { Kesesuaian materi pada Macromedia Flash } 8 \text { dengan materi pokok dalam } \\
\text { Kompetensi dasar }\end{array}$ & 4 \\
\hline 5 & $\begin{array}{l}\text { Kesesuaian materi pada macromedia flash } 8 \text { dengan tujuan pembelajaran yang } \\
\text { akan dicapaii }\end{array}$ & 4 \\
\hline 6 & Penyajian gambar pada macromedia flash 8 menarik dan proporsional & 4 \\
\hline 7 & Kemampuan media dalam meningkatkan motivasi belajar siswa & 3 \\
\hline 8 & Fleksibilitas penggunaan media dalam pembelajaran & 3 \\
\hline 9 & Kemudahan media untuk memahami materi yang akan disajikan & 3 \\
\hline 10 & Kemampuan media untuk menambah pengetahuan siswa & 4 \\
\hline \multicolumn{2}{|r|}{ Jumlah Skor yang Diberikan Responden (R) } & 38 \\
\hline & Jumlah Skor Maksimum (SM) & 40 \\
\hline
\end{tabular}

Dari nilai akhir praktikalitas respon guru yaitu $95 \%$ diatas dapat dikatakan "sangat praktis" pada kategori penilaian Riduwan dan 
Sunarto (2012:23) yaitu kategori pertama dengan presentase $81-100 \%$ untuk itu hasil praktikalitas media pembelajaran berbasis macromedia flash dinyatakan praktis digunakan.

\section{SIMPULAN}

Simpulan hasil analisis data adalah Multimedia interaktif yang dikembangkan telah sesuai dengan kebutuhan dilapangan dan tuntutan kurikulum. Dengan demikian, dapat disimpulkan bahwa media pembelajaran berbasis macromedia flash 8 dinyatakan sudah valid serta dapat digunakan dalam proses pembelajaran kelas IV tema 8 subtema 2 pembelajaran 1 dan 2 . Hal ini diketahui dari hasil uji validitas dari tiga orang ahli yaitu ahli media $90,6 \%$, ahli materi $92 \%$ dan ahli bahasa $88 \%$.

Multimedia interaktif yang dikembangkan peneliti dinyatakan praktis. Hal ini diketahui dari hasil uji praktikalitas dari guru kelas IV SDN 32 Bungo Pasang dan guru kelas IV SDN 24 Jati Gaung dengan persentase sebesar $92,5 \%$ dan $95 \%$. Hasil respon siswa kelas IV SDN 32 Bungo Pasang dan siswa kelas IV SDN 24 Jati Gaung terhadap media pembelajaran berbasis macromedia flash 8 juga sangat praktis, hal ini diketahui dari hasil persentase sebesar $88 \%$ dan $82,6 \%$. Artinya guru dan peserta didik merasa senang dengan adanya media pembelajaran ini karena dapat membantu dalam proses pembelajaran.

\section{DAFTAR RUJUKAN}

Andini, Selfi Rahmi., Fitria. Y. 2021. Pengaruh Model RADEC Pada Pembelajaran Tematik Terpadu Terhadap Hasil Belajar Peserta Didik Sekolah Dasar. Jurnal Basicedu, 5(3), 1435-1443.

Daryanti, Desyandri \& Fitria. Y. 2019. Peran Media Dalam Pembelajaran Seni Budaya Dan Keterampilan Di Sekolah Dasar. Edukatif: Jurnal Ilmu Pendidikan, 1(3), 215-221.

Elisa, L., Fitria, Y., Padang, U. N., Padang, U. N., Padang, U. N., \& Padang, U. N. 2019. Application Oflearning Model Auditory, Intellectually, Repetition (Air) To Increase Student Activity And Learning Outcomes In 2013 Curriculum Integrated Thematic Learning In Class Iv Sdn 06

Hand Of Padang. 1(2), 156 162.

Fitria, Yanti. 2016. Penguatan Pengajaran Guru Sains Level Dasar Dengan Strategi Pendidikan Karakter Berbasis Literasi Sains. KONASPI VIII:

Universitas Negeri Jakarta

Fitria, Yanti. 2018. Landasan Pembelajaran Sains Terintegrasi (Terpadu) Untuk Level Dasar. Padang: Sukabina Pers.

Hamalik. 1994. Media Pendidikan. Bandung: Citra Aditya Bakti Indriyani, D., Desyandri., Fitria, Y \& Irdamurni. 2019. Perbedaan Model Childern's Learning In Science (CLIS) Dan Model Scientific Terhadap Hasil Belajar Siswa Pada Pembelajaran 
Fadhilla Imanda Azzahra, Yanti Fitria: Pengembangan Multimedia ....

Tematik Terpadu Di Kelas IV SD.

Jurnal Basicedu, 3(2), 627-633

Mardhatillah dan Trisdania, E. 2018.

Pengembangan Media

Pembelajaran Berbasis

Macromedia Flash 8 untuk

meningkatkan Kemampuan

Membaca Siswa di Sd Kelas II

Negeri Paya Peunaga Kecamatan

Meuboro. Bina Gogik, 5(1), 2355-3774

Rahmi, Mar'atush Sholichah

Muntaha, Dkk. 2019.

Pengembangan Media

Pembelajaran Interaktif

Macromedia Flash 8 Pada

Pembelajaran Tematik Tema

Pengalamanku.International

Jurnal Of Elementary Education.

Vol. 3 No. 2, Mei 2019, Hal 178

-185 .

Sugiyono. 2018. METODE

PENELITIAN PENDIDIKAN

(Pendekatan Kuantitatif,

Kualitatif, Dan $R \& D)$. Bandung:

Alfabeta.

Taupik, Riska Putri., Fitria. Y. 2021.

Pengaruh Model Pembelajaran

Project Based Learning

Terhadap Pencapaian Hasil

Belajar IPA Siswa Sekolah

Dasar. Jurnal Basicedu, 5(3), 1525-1531

Wahyugi, R \& Fatmariza. 2021.

Pengembangan Multimedia

Interaktif Menggunakan Software

Macromedia Flash 8 Sebagai

Upaya Meningkatkan Motivasi

Belajar Siswa Sekolah Dasar.

Jurnal Basicedu, 3(3), 785-793. 